\title{
THE USE OF TEACHERS' QUESTIONING STRATEGIES TO STIMULATE STUDENTS' CRITICAL LITERACY: A CASE OF TWO ENGLISH LECTURERS IN INDONESIA
}

\author{
Siti Aimah \\ English Education Department, Universitas Muhammadiyah Semarang, Indonesia \\ E-mail: siti.aimah@unimus.ac.id \\ Bambang Purwanto \\ English Language and Literature Department, Universitas Negeri Semarang, Indonesia \\ E-mail: bambangpurwanto@mail.unnes.ac.id
}

\begin{abstract}
APA Citation: Aimah, S., \& Purwanto, B. (2018). The use of teachers' questioning strategies to stimulate students' critical literacy: A case of two English lecturers in Indonesia. Indonesian EFL Journal, 5(1), 27-36. doi: 10.25134/ieflj.v5i1.1608.
\end{abstract}

\begin{abstract}
To create an effective teaching, teachers should consider the use of questioning strategies to not only elicit students' attention, but also stimulate their critical literacy. This study aims to know the use of questioning strategies used by the English lecturers in the classrooms. An in-depth research was done to provide the information dealing with the reasons of using the questioning strategies and the questioning strategies used to stimulate students' critical literacy. A case study was carried out by involving two English lecturers of Universitas Muhammadiyah Semarang, Indonesia. Both of them taught the second semester students in Reading class and Language Testing class in the Academic Year of 2017/2018. Data were collected through videorecordings and interview with both lecturers. The findings showed that both lecturers used question-planning strategies and question-controlling strategies as proposed by Xuerong (2012) and Walsh (2011). To stimulate the students' critical literacy, open-referential questions and follow-up questions were posed to encourage them to be more critical. Wait-time given by the lecturers also helped the students answered the questions, and their questions were more accurate, elaborate, and reasonable.
\end{abstract}

Keywords: critical literacy; effective teaching; question-controlling strategies; question-planning strategies; teachers questioning strategies.

\section{INTRODUCTION}

Questioning has an important role to create an effective teaching (Sun, 2012; Yang, 2017). The questions function to not only elicit the students' attention, but also stimulate students' critical literacy (Tofade, Elsner, \& Haines, 2013; Zhao, Pandian, \& Singh, 2016). Critical literacy which is closely related to critical thinking can be developed through formal instruction (Yang, Newby, \& Bill, 2005). In this case, what the teachers should do is by providing the questions to stimulate them to be critical. Through questions, the teacher helps the students uncover what has been learnt, explore the subject matter, and enhance the discussion and interaction with the others (McComas \& Rossier, n.d ; Yang, 2017). Therefore, it is very important for the teacher in posing questions to ascertain the level at which the students understand (or misunderstand) the certain concepts presented during lecture so that the students' critical literacy could also be seen or measured. The teacher, in this case, can pose some questions which are also used to engage or encourage students' active participation, draw the students' attention, and motivate their interest in a classroom (Fitriati, Isfara, \& Trisanti, 2017; Yang, 2017). By posing some questions, it can 


\section{Siti Aimah \& Bambang Purwanto}

The use of teachers' questioning strategies to stimulate students' critical literacy: A case of two English lecturers in Indonesia

broaden the students' thought to promote their critical literacy in the classroom.

Teachers' questioning in the classroom; however, doesn't always play its proper role. In daily teaching, for example, there still exist some problems, such as asking without response, and asking just for asking. The students are sometimes not familiar with the certain vocabulary used by the teacher. It makes the students difficult to grasp the meaning of the questions. Consequently, the students become reluctant to respond the teacher's question. They still keep silent even though the questions are nominated to them. Therefore, the teacher must solve the problems existing in the process of English classroom questioning and put forward effective strategies for classroom teaching.

According to Xuerong (2012) and Walsh (2011), questioning strategies are classified into two categories: question-planning strategies and question-controlling strategies. Question-planning strategies function to elicit response and identify problems, better understand students' knowledge, and invite for further discussions. While question-controlling strategies are procedures used by teachers to ask questions in the classrooms in order to distribute turn-taking and encourage participation (Rido, 2017).

Xeurong (2012) mentions questionplanning strategies consist of asking openreferential, close-display, rhetorical, and follow-up questions, and asking for supporting data. Meanwhile, Questioncontrolling strategies comprise phrasing the question first and calling on the student, calling on specific students to answer questions, asking questions to entire class, encouraging students to consult their classmates before answering questions, encouraging students to initiate questions, moving closer to students when asking questions, repeating question when there is no response, and modifying question when it is not understood.

Some researchers have also conducted study focusing on teachers' questioning strategies. First, Rido (2017) focused his study on the use of questioning strategies of Indonesian vocational English master teachers. The findings showed that the master teachers employed an interactive style of teaching. They used close-display, open-referential, and follow-up questions by nominating specific students to answer questions, asked questions to the entire class, and repeated questions when there was no response. The strategies made the teachers could control the lessons, guide the students towards a particular response, and promote interactions. Second, Fitriati, Isfara, and Trisanti (2017) investigated teachers' questioning strategies to elicit students' verbal responses in EFL classes at a secondary school. The findings revealed that questioning skills have an impact on improving students' verbal responses in the classroom interaction. Teachers must apply comfortable and appropriate questioning strategies that were suitable for students and the class' context of situation so that the purposes of questioning can be achieved, including developing students' English proficiency, measuring their abilities, and motivating them to speak the language. Meanwhile, Yang (2017) analyzed the problems of classroom questioning. The problems were commonly about lack of waiting time, lack of proper feedback, and unequal distribution of questions. To solve the problems, a series of strategies for English classroom questioning was required, and it included preparation questions before questioning, controlling while questioning, and giving feedback after questioning.

Considering the importance of questioning strategies used by the teachers, none of them focuses on how to simulate students' critical literacy. Therefore, this study aims to provide an in-depth information of the teaching practices in Universitas Muhammadiyah Semarang focusing on the use of questioning strategies used by two lecturers. Further, it is also an attempt to know the types of questioning strategies used to stimulate the students' critical literacy. Based on the aims of the study, the research questions raised are as 
follows: 1) What are the questioning strategies used by the lecturers in the classrooms and the reasons?, 2) What types of questioning strategies are used to stimulate the students' critical literacy?

\section{METHOD}

A case study was conducted in which lessons of two English lecturers were employed in this study. The selected participants were two English lecturers (one male and one female) in English Education Department of Universitas Muhammadiyah Semarang, Indonesia. The male lecturer (L1) aged 30 years old was a philosophy of doctor, while the female lecturer (L2) aged 35 years old was a master degree. Both of them have been teaching English for about 8 years.

Two classes were investigated in this study. First, the investigated class was Reading class for the second semester with the amount of 20 students. Second was Language Testing class for the fourth semester consisting of 13 students. Both classes comprised students from Indonesia and Thailand in which the average of their academic level was equal even though they were in different level of semester.

The data for this study were the transcripts of two video-recordings English lessons and the interview with both lecturers. The two lessons taught by the two English lecturers were video-recorded and the whole class interactions were transcribed. The transcription data were then analyzed qualitatively based on Walsh (2011) and Xeurong (2012). While the result of interview with the two lecturers was analyzed qualitatively in which the function was to find out the lecturers' reasons of using questioning strategies in their classroom.

\section{RESULTS AND DISCUSSION \\ The questioning strategies used by the lecturers and the reasons}

The results of video-recordings and interview showed that the two English lecturers used both question-planning and question-controlling strategies in their classrooms.

\section{Question-planning strategies Open-referential question}

Referential-question deals with the question in which the answer is not already known by the teacher. It means that it requires interpretations and judgments from the interlocutor. The use of referential-question could be seen in Extract 1 and 2.

Extract \#1

L1 : First of all (,) I have one question for you from the title above (.) The title of the computer crime here (.) what do you think the passage about (?) Before reading(.) (wait-time)

S : Well (,) the passage is about hacker (.) Yes (,) hacker (.)

L1 : Okay (,) Hacker (.) Do you know what is hacker (?)

$\mathrm{S}$ : Yes (,) someone who hacks the sites on internet (.)

From the Extract 1, it shows that L1 asked the students by using wh-question commonly characterized by using what, why, who, etc. to provide the contextual information about situations, events, purposes, etc. (Hamiloğlu, 2012; Walsh, 2011). In delivering the students' interpretation, the students were required to critically evaluate their reading. The lecturer said that through open-referential questions, the students were demanded to think critically based on their knowledge. They must be able to connect their understanding about the text with the certain context. It required deep thinking to evaluate about that. They also had to give their opinion about what they had learnt. It is in line with Rido (2017) and Zhao, Pandian and Singh (2016) who state that open-referential questions stimulate the students' critical thinking. They needed to give longer responses toward the particular questions posed to them. Similarly, Walsh (2011) says that referential question is used to promote discussion and get longer responses.

Extract \#2
L2 : In your opinion, what is the function (/) purpose of the Public Speaking (?) (wait-time)
S : To share the public (.) 


\section{Siti Aimah \& Bambang Purwanto}

The use of teachers' questioning strategies to stimulate students' critical literacy: A case of two English lecturers in Indonesia

L2 : What is to be shared (?)

$\mathrm{S}$ : Some topics (.)

Based on Extract 2, L2 posed the referential-question demanded the student to give longer information about the purpose of the topic discussed. Yet, the student only gave short answer to the question. Based on the lecturer's information, it was because the student was not confident enough to speak. She was afraid to make mistakes in speaking English. That is why it influenced her in expressing her ideas in front of the others.

\section{Close-display question}

Close-display questions, according to Walsh (2011), are the questions asked to the students in which the teachers already know the answer. They require the students to display what they know. They have some functions: to elicit the students' response, to check the students' understanding, to guide the students towards a particular response, to promote the students' involvement, and to check the students' concept. Close-display questions asked by L1 during teaching and learning process in the classroom could be seen in the following extract:

Extract \#3

L1 : Okay (,) finish (.) Now let's go on to the some word unfamiliar for you e.g. like bug

(.) Do you know bug here (?)

$\mathrm{S}$ : Error (.)

L1 : Bug bisa jadi kaya sampah yang tidak penting and then corrupt I think it's very easy (.) Corrupt is.... to cause error appear in file data or number reliable (.) Different from construction e.g. DPR kaya gitu beda lagi (,) disini lebih ke eror datanya (/) tidak bisa dibuka and then next one some unfamiliar words for you e.g which one crook (.) What is crook (?)

SS : Penipu

L1 : Dishonest (/) penipu juga sama atau ....... Dishonest tidak jujur and then is there any else (?) something unfamiliar word (?)

SS : (silence)

L1 : Swindler (.) Okay (,) what is swindler (?)

SS : Penipu

Extract 3 shows the display questions shown with the use of wh-questions and yes/no questions. Dealing with the use of wh-question, the lecturer (L1) checked the students' understanding about what they had learnt, i.e. their understanding about the term of bug. The use of this question made the lecturer easier in measuring what extent to which the students' understanding about the text. Then, to check the students' concept about the similar topic, the lecturer also asked by using yes/no questions in which it actually aimed to promote the students' involvement in the classroom.

The similar condition above also happens in the Extract 4 in which L2 used wh-question to guide students toward a particular response. The use of close-display questions could be seen in the following Extract.

Extract \#4

L2 : What time do you wake up today (?)

$\mathrm{S}$ : Delapan (,) Mrs (.)

L2 : At eight (?)

$\mathrm{S}$ : No no no (,) at nine (.)

L2 : At eight (?) No no at nine (?) Jadi malah nambah jam 9 (.) Okay (,) so if I am not mistaken (,) today we are gathering here to at least to do some practices about (.) What is your subject (?) Public speaking and also you meet your new friends in public relation (.) Do you think that both of the subjects has the correlation (?) And here we go the man who always come late after their friends (.) So please have a sit (.) Do you think that public speaking and public relation have correlation (?)

SS : Yes (.)

L2 : In what way (?)

SS : Speaking (.)

From Extract 4, it shows that L2 actually rebuked one of the students who came late to the classroom. To do that, L2 asked the students with $w h$-question by asking the time he woke up that made him late to come to the class. However, there was inconsistent answer from the student making L2 ascertained what he said. To ascertain the condition, then, L2 asked the students with yes/no-question to have the choral response. For having the choral response from all the students, the lecturer used close-display questions. She got easier in controlling the class by using the type of question which was not only for guiding the students' response, but also for checking the students' understanding about what they had learnt. It 
concurs with Xeurong (2012) that the use of questions stimulates the students to speak and improve the interaction in the classroom. The use of display-questions can also encourage language learners to get interested in and be active in the classroom.

From the Extracts above, they show that display-questions are commonly characterized with short responses from the students. It is in line with Walsh (2011) who states that display-questions require short answers containing small pieces of information. It means that the responses given tend to be simple, restricted, and commonly contain one or two words.

\section{Rhetorical question}

In the Extract below, rhetorical questions were used by the lecturer (L2) during teaching and learning process in the classroom.

Extract \#5

L2 : Of course many areas which covered that Public Relation need to be accessed (,) (Bahwa pekerjaan Public Relation itu tidak hanya dalam satu bidang saja)(,)bagaimana actually in Public Speaking or actually in broader areas ( $d i$ dalam situasi yang lebih luas seseorang yang menyampaikan pesan) (,) it doesn't talk only about how is our speaking (?) how is our pronunciation (?) how is our skill (,) but also your strategies (?) your tactics (?) your maping in finishing your job (?) (semua orang perlu maping) (.) Even though in Public Speaking you should also define (anda juga harus menentukan apa yang anda mau sampaikan?) (,) which start (?) (saya mau memulai dari mana (?) what should be ended (?) (kapan saya memulai dan apa yang merupakan informasi yang harus saya berikan (?) in the end of the season misalnya (?) Let's see then to save the time because if I let you read this (,) maybe we will finish next month (.) So (,) what is Public Relation? If you are allowed to read please Lastari first definition by Harlow (.)

From Extract 5, a series of rhetorical questions were posed by the lecturer to the students. Rhetorical questions are questions used not to find out information or elicit an answer. L2 as seen in Extract 5 asked the students by using rhetorical questions, however, the questions posed did not really require the students' answer even though they were possible to answer. During explaining, L2 depicted the condition in which she demanded the students to critically think what should be considered and/or prepared for facing the certain situations. L2 used the rhetorical questions as assertions of what she was talking about to emphasize the important points of the related topic.

Dealing with the use of rhetorical question which did not expect the answer, it can be categorized as redundant interrogatives. It is because rhetorical question is only seen as assertions of what is talking about.

\section{Follow-up question}

The next strategy used by the lecturer is follow-up questions. Those questions are characterized by using $w h$-questions posed to a specific student to respond.

Extract \#6

L1 : Okay (,) first of all (,) I will revise about how to pronounce this one Arya (.) How to pronounce this word (?) Increase (.) Increase (,) agak panjang (.) Increasing it is safer not to use computer (,) bacanya bukan komput tapi kompyuter (.)

$\mathrm{S}$ : Kompyuter (.)

L1 : If you want to buy something in restaurant (,) menunya mana (?)

SS : Repeating and laughing (.)

L1 : If we use it with the pronunciation menu (,) computer (.) What would your answer be in this condition (?)

$\mathrm{S}$ : (silence)

L1 : Okay (,) Nadya. Do you agree with this sentence (?)

$\mathrm{S}$ : Sentence what sir (?)

L1 : sentence not to use laptop (,) mobile phone (,) technological on the internet (.)

$\mathrm{S}:$ : No (.)

L1 : Why didn't you agree with (?) (wait-time)

$S$ : Because in our life we must know about the information and our situation here in globalization condition (.)

Extract 6 shows that L1 asked closedisplay question posed to a specific student to be more responsible to answer. After that, 


\section{Siti Aimah \& Bambang Purwanto}

The use of teachers' questioning strategies to stimulate students' critical literacy: A case of two English lecturers in Indonesia

L1 continued his conversation by using further questions which are still related to the topic. L1 gave an analogy to the entire class to make the students easier in understanding what he was talking about. Then, follow-up questions were posed by using $w h$-question to all students. However, no one of them gave a response. Seeing that condition, L1 asked the other student to respond his follow-up question. Unfortunately, she did not focus on the lesson which made her confused to get the point in which it demanded L1 to describe the condition. Having got the response from the student, L1, then, continued to ask the question to the same student to develop her argument. In this case, L1 combined the strategies of question at the same time to stimulate and dig the student's ability to think more critically.

Extract \#7

L2 : Okay then, Saya mau tanya (.) Do you think that Public Relation and Public Speaking is different (?) (wait-time)

L2 : Aini (?)

$\mathrm{S}$ : Yes different (.)

L2 : In what way (?)

$\mathrm{S}$ : The purpose (.)

L2 : The purpose (?) Good (.) What is the purpose of the Public Speaking and Public Relation(?)

$\mathrm{S}$ : Public Speaking (.)

L2 : In your opinion (,) what is the function/purpose of the Public Speaking (?)

$\mathrm{S}$ : To share the public (.)

L2 : What is to be shared (?)

$\mathrm{S}$ : Some topics (.)

L2 : Sesuatu (?)

$\mathrm{S}$ : Some topics (.)

L2 : Some topics (?) Why do you think the topic should be delivered to public (?)

$\mathrm{S}$ : I don't know (.)

From Extract 7, L2 began her questions by using close-display question which was then continued with a series of follow-up questions. L2 posed those questions to a specific student in order to maximize her ability in communication and stimulate her to be more active in the classroom. Rido (2017) mentions follow-up questions are aimed to stimulate the students' involvement in the discussion of the classroom. The use of the questions can also stimulate the recall of prior knowledge, promote comprehension, and build critical-thinking skills (Tofade, Elsner, \& Haines, 2013). Both lecturers added that follow-up questions stimulated the students to dig their knowledge deeply. They carefully answered the questions posed to them based on their critical thinking.

\section{Question-controlling strategies}

Question-controlling strategies refer to ways or procedures used by the teacher in the classroom (Rido, 2017). The following is the findings found in the use of questioncontrolling strategies.

Phrasing the question and calling the student

The following strategy is used by the lecturer in posing the questions to a specific student.

Extract \#8

L1 : Usually we find information from the computer or internet that's good. Is there any answer (?) (wait-time)

L1 : Okay (,) Safira (?)

$S$ : As computer crime increasing (,) it is safer not to use the computer (.) What would your answer be (?) Computer guard (.)

Extract 8 shows that L1 firstly posed his question to a specific student to respond. L1 preferred to use the strategy of phrasing the question and then calling the student to answer. It was done in order all students would have the same responsibility from the others to think first what the answer of the question is. Having given wait-time to think in which the teacher waits after asking question before getting a response (Walsh, 2011), then L1 nominated the specific student to answer. It was done to make the lecturer easier in controlling the class. The student, in this case, had also been ready and confident to give the response to the lecturer in front of the others. 


\section{Calling on specific students to answer questions}

The similar strategy above is shown in the following strategy in which the lecturer preferred to nominate a specific student to answer to mention the question.

Extract \#9

L1 : Ade said that computer crime is bad, it's not good behaviour (.) Indra (,) is there any else want to add additional information about computer crime (,) the opinion about computer (.) Indra setiawati (?)

$\mathrm{S}$ : Yes $\operatorname{sir}($.)

L1 : What do you think about computer crime (?)

$\mathrm{S}$ : It's not good (,) but they can merugikan people and then...

\section{Extract \#10}

L2 : Well, that's very awesome answer (.) Habib, can you tell me (,) can you tell us (?) Do you think that public speaking and public relation have correlation (?) You can say no if you don't want to answer (.)

$\mathrm{S} \quad$ : Yes (.)

Based on Extract 9 and Extract 10, there is a similar condition in which both lecturers (L1 and L2) nominated the specific student to answer rather than firstly mentioned the question to the student. They preferred to do that to avoid any student who ignored the questions posed to them. When the student was in a situation in which he/she must give the response, he/she would have a responsible to think what the answer was. It concurs with Walsh (2011) who states by nominating the specific student to answer, it can help to encourage his/her participation in the teaching and learning process. Rido (2017) also adds that this strategy gives an opportunity to the students to respond the teacher's questions.

However, the strategy used by the teachers often made the students startled because they had not been ready to answer yet. Consequently, the specific student pointed by the lecturer could not give the longer response to the teacher. He/she did not have any confidence to speak since she/he was not ready yet to answer (see Extract 10).

\section{Asking questions to entire class}

To elicit the students' response and check their understanding about a certain topic, the lecturers commonly used this strategy in the classroom. To see more in detail, it could be seen in Extract 11.

\section{Extract \#11}

L1 : Finish? Now let's go on to the some word unfamiliar for you e.g. like bug. Do you know bug here?

SS : Error

L1 : Bug bisa jadi kaya sampah yang tidak penting and then corrupt I think it's very easy. Corrupt is.... to cause error appear in file data or number reliable. Different from construction e.g. DPR kaya gitu beda lagi, disini lebih ke error datanyal tidak bisa dibuka and then next one some unfamiliar words for you e.g. which one crook. What is crook?

\section{SS : Penipu}

L1, in Extract 11, checked the students' knowledge about a certain topic that they had discussed. He posed the question to the entire class to get attention and elicit the response. The questions posed by the teacher to the students are keys in focusing the students' attention. This strategy was also effective to stimulate the students' participation in the classroom. Even the use of this strategy could help shy students to get the others' support to participate in the classroom (Rido, 2017).

\section{Repeating questions}

Repeating questions were commonly used by the lecturers when there were no responses from the students.

Extract \#12

L2 : Okay (,) do you think that we just only need our vocabulary (,) and our pronounciation (?) Do you think when we are doing speech and speaking we just need language components only (?)

$\mathrm{S}$ : (silence)

L2 : Okay (,) do you think when we are doing speech and speaking we just need language components only (?) Habib (?)

$\mathrm{S}$ : No (.) When we are going to speak in audience (,) ..... define the meaning of our speaking and also we can do some of 


\section{Siti Aimah \& Bambang Purwanto}

The use of teachers' questioning strategies to stimulate students' critical literacy: A case of two English lecturers in Indonesia

information that apa (?) for relation what are we talking about (.)

From Extract 12, L2 did repetition for her questions because there was no response from the students. Repetition was done by L2 to ascertain that the students really understood her question. Hopefully, when they got the point of the questions, they could give the teacher responses. It is in line with what Fitriati, Isfara, and Trisanti (2017) said that repeating questions are basically used to stimulate the students' more detailed responses. Without repeating, for those who did not understand what the question was, they only would be silent and did not give a response. Hence, in some contexts, repetition is very required to support the quality of teaching and learning in the classroom.

\section{The questioning strategies used to develop students' critical literacy}

The findings show that open-referential and follow-up questions were the strategies used by the lecturers to develop students' critical literacy. Open-referential questions were posed to the students to seek the students' interpretation about what they had learnt. Even though both lecturers did not often use this type of questions, the lecturers admitted that through those questions, they would get many unpredictable answers from the students.

Students' critical literacy basically can be influenced by the level of questions posed by the lecturer in the class. The quality of the questions posed also determines the level of students' critical literacy. Through questioning, the students built their understanding and developed their critical thinking by expressing their own opinions based on their critical review, conveying their arguments, etc. That is why the lecturers must think and prepare what type of questions used to stimulate the students to be more critical. Based on the interview, the use of this question also helped the lecturers in achieving the information. The students attempted to think more deeply and critically to convey their arguments. It is in line with
Feng (2013) who says that referential questions are used to challenge students to think and respond at higher levels of cognition, to stimulate creativity and to involve students by asking for their opinions.

The second strategy is follow-up questions. Follow-up questions were actually the most common strategy used by the lecturers to stimulate the students' critical literacy rather than open-referential questions. The lecturers said that the easiest thing to do in stimulating their high-order thinking was by nominating a specific student to answer the questions posed to them. They mentioned that even though the student usually only gave a short response when the lecturer tried to pursue to which his/her answer was by asking the other questions (see Extract $6 \& 7$ ), it stimulated him/her to think more deeply. It proves that follow-up question also stimulated the students to be more critical through eliciting longer and complex responses.

To stimulate the students' critical literacy through the strategies above, it was also required to provide the wait-time as proposed by Feng (2013). By providing wait-time, the students not only have the adequate time to reflect, but also formulate their responses (Zhao, Pandian \& Singh, 2016). As seen in the Extracts above, the students needed wait-time to formulate their answer. When they were given an opportunity to prepare their responses, they answered the questions posed to them, and their answers become more accurate, elaborate, and reasonable rather than directly answered the question without having the wait-time to think. The lecturers said that not all students had the same level of knowledge. Some of them could think quickly, and the rest needed the wait-time to think what the answers of the questions posed to them. To face the situation, the lecturers gave an opportunity to them to prepare their responses through the waittime given. Consequently, they were responsible to answer the questions based on their level of understanding. 


\section{CONCLUSION}

The questioning strategies used by the teachers in the classroom are influenced by the quality of the teachers themselves. Questioning proves for not only stimulating the students' attention, but also determining students' critical literacy (Zhao, Pandian \& Singh, 2016). To develop the students' critical literacy, it was provided with the questioning strategies (question-planning strategies and question-controlling strategies) used by the lecturers. However, not all questioning strategies promote the students' critical literacy. Among the strategies used, open-referential question and follow-up question enabled the lecturers to stimulate the students' high-order thinking.

In pedagogical setting, the use of the questioning strategies helped the lecturers in managing and controlling the class, and stimulating the students' response and critical literacy. Therefore, the lecturers should be aware that the use of questioning strategies has a big impact on students' learning. They should plan the use of questions that encourage the students to promote their involvement. It will also be better for the lecturers to pose the questions to the volunteer students so that the other students will have the opportunity to respond the questions. Next, the students, in this case is English Education students, should be taught with the questioning strategies that benefit to their future teaching career so that they can promote the students' engagement in the classroom.

\section{REFERENCES}

Feng, Z. (2013). Using teacher questions to enhance EFL students' critical thinking ability. Journal of Curriculum and Teaching, 2(2), 147-153.

Fitriati, S. W., Isfara, G. A. V., \& Trisanti, N. (2017). Teachers' questioning strategies to elicit students' verbal responses in EFL classes at a secondary school. English Review: Journal of English Education, 5(2), 217-226.

Hamiloğlu, K. (2012). The impact of teacher questions on student learning in EFL. Journal of Educational and Instructional Studies in the World, 2(2), 1-8.

McComas, W. F., \& Rossier, L. A. (n.d.). Asking more effective questions. Retrieved from https://uwaterloo.ca/centre-for-teachingexcellence/sites/ca.centre-for-teachingexcellence/files/uploads/files/asking_better_quest ions.pdf.

Rido, A. (2017). What do you see here from this picture? Questioning strategies of master teachers in Indonesian vocational English classroom. TEFLIN Journal, 28(2), 193-211.

Sun, Z. (2012). An emphirical study on new teacherstudent relationship and questioning strategies in ESL classroom. English Language Teaching, 5(7), 175-183.

Tofade, T., Elsner, J., \& Haines, S. T. (2013). Best practice strategies for effective use of questions as a teaching tool. American Journal of Pharmaceutical Education, 77(7), 1-9.

Yang, H. (2017). A research on the effective questioning strategies in class. Science Journal Education, 5(4), 158-163.

Zhao, C., Pandian, A., \& Singh, M. K. M. (2016). Instructional strategies for developing critical thinking in EFL classrooms. English Language Teaching, 9(10), 14-21. 
Siti Aimah \& Bambang Purwanto

The use of teachers' questioning strategies to stimulate students' critical literacy: A case of two English lecturers in Indonesia 